\title{
A TANÍTÁS METAFORÁI
}

\section{Szerző:}

Pinczésné Palásthy Ildikó (PhD)

Debreceni Református Hittudományi Egyetem

Szerző e-mail címe: palasthy.ildiko@drhe.hu

\section{Lektorok:}

Mező Ferenc $(\mathrm{PhD})$

Eszterházy Károly Egyetem

Hanák Zsuzsanna (PhD)

Eszterházy Károly Egyetem

...és további két anonim lektor

\section{Absztrakt}

Tanulmányunkban a metafora fogalom értelmezésén túl a metafora-módszer néhány pedagógiaipszichológiai alkalmazási módozatára mutatunk rá, majd ismertetjük saját vizsgálatunkat. Eredményeink igazolják, hogy tanítójelölt hallgatók körében is hatékonyan alkalmazható a metafora-módszer: válaszaik mentén sajátos asszociációs háló rajzolódik elénk. A tréning-keret lehetőséget nyújt a fókuszált fogalmak mögötti nézetek, vélemények feltárására, valamint az élmények feldolgozására.

Kulcsszavak: metafora, kutatási módszer, tanítóképzés

Diszciplinák: pedagógia, pszichológia

\section{Abstract}

METAPHORS OF TEACHING

In our study, we attempt to highlight both the interpretation of the concept of metaphor and the the introduction of the so-called 'metaphor-method', and, we also point out some of the pedagogicalpsychological ways of applying the 'metaphor method'. Finally, we intend to present the results of ous research. Our results prove that 'metaphor-method' can effectively be used among the primary school teacher candidate students: along with their answers, a special association network is drawn to us. The training framework provides an opportunity to explore the views and opinions behind the targeted concepts and to process the experiences.

Keywords: metaphor, research method, primary school teacher training

Disciplines: pedagogy, psychology

Pinczésné Palásthy Ildikó (2019): A tanítás metaforái. OxIPO - interdiszciplináris tudományos folyóirat, 2019/1, 23-31. doi: 10.35405/OXIPO.2019.1.23 
Nil novi sub sole. (Nincs íj a nap alatt.)

Horatius: Ars poetica

A metafora szó az ókortól ismert kifejezés. Gazdag produkciófelületét mi sem bizonyítja jobban, minthogy több tudomány (irodalom, retorika, stilisztika, stb.) fogalmi rendszerében is fellelhetô.

Tanulmányunkban először a metafora fogalom értelmezésére fókuszálunk, majd a metafora-módszer néhány pedagógiai-pszichológiai alkalmazási módozatára mutatunk rá, végül ismertetjük saját, e téma és módszer vonatkozásában tanítójelölt hallgatók körében végzett vizsgálatunkat.

\section{A szóképek}

A szókép elsődlegesen a stilisztika által használt kifejezés. Már az ókori görögök felismerték a nyelv azon sajátos viselkedését, hogy a megnevezett dolog önmagán túl valami mást is jelenthet. Innen eredeztethetô a görög trópus (fordulat) megnevezés is. Fordulat, forgatás, átforgatás, átvitel, azaz egy fogalom, jelenség nevének átvitele valamely másik fogalomra, jelenségre a köztük lévő kapcsolat alapján. Tehát a szókép az a nyelvi-fogalmi jelenség, amely valamilyen jelentésátvitelt tartalmaz.

„A szóképek fő funkciója az, hogy a mondanivalót szemléltetéssel, elképzeltetéssel, az elvont fogalom megérzékítésével illetve az érzéki fogalomnak érzéki képhez való kapcsolásával megvilágítsa." (Fábián, Szathmári és Terestyén, 1958, 80. o.) Ez a névátvitel sajátos szerkezete révén valósul meg: két részből, egy fogalmi síkból (vagy egyszerúen fogalomból), és egy képi síkból (egyszerúbben: kép) áll. A fogalmi és a képi sík összekapcsolásának módja határozza meg a szókép típusát. (Kövecses, 1998, Vámos, 2001)

A hazai és külföldi jelentéstani és stilisztikai szakirodalom a szóképeknek két fő kategóriáját különíti el a névátvitel kritériuma, a fogalmi és képi sík kapcsolatának jellege alapján (Fábián, Szathmári és Terestyén, 1958):
1) A névátvitel történhet a két fogalom, jelenség valamely közös vonása alapján, például külső és belső hasonlósága alapján. Ilyenkor metaforáról beszélünk.

2) „Ha a névátvitelt a két fogalom, jelenség, dolog közt levő térbeli, időbeli, anyagbeli érintkezésen alapuló kapcsolat vagy ok és okozat viszonya indokolja, metonímiáról van szó.” (Fábián, Szathmári, Terestyén, 1958, 79. о.).

A metonimia tipusú képekeben a fogalmi és a képi sík között a kapcsolatot az érintkęés teremti meg. Az érintkezés különféle jellegû lehet: például jelölhetünk egy dolgot a helyével (alszik a ház), idejével (a jövő gyermekei), anyagával (egymást péppé verik).

A metafora esetében a névátvitel két jelentés részleges közösségén, vagy két jeltárgy, a fogalmi és a képi oldal hasonlóságán alapul. A csoport névadója a metafora (gör. „átvitel”): az egyik dolog nevét átvisszük a másikra. Arisztotelész, akit a stilisztika atyjának is szoktak nevezni, Poétikájában így ír a metaforáról: „A jó metaforák használata a hasonló vonások felismerésén alapul." (Arisztotelész, 1974, 54.o.).

S valóban, a jelenséget mindannyian ismerjük és használjuk, fogalmi szinten is az általános mûveltség része, gyakorlatilag érettségi anyag. Így tudjuk, hogy több típusa létezik. Arisztotelész még csupán egy trópust ismer, a metaforát, Quintilianus már 14 fajtáját különbözteti meg (Fábián, Szathmári és Terestyén, 1958).

A metaforaelméletek különbséget tesznek a költői, múvészi és a köznyelvi metaforák (pl. asztalt bont vagy aranyos gyermek) között. De legáltalánosabban a szerkezeti szempont szerinti felosztás ismert:

- teljes a metafora, amennyiben a képi és a fogalmi sík egyaránt megjelenik. Például:. „Szívemnek gyöngyháza, lelkem Iluskája”,

- egyszerú vagy egytagú a metafora, ha csupán a képi sík adott. Például: „Amott ül egy túzok magában".

A metaforával rokon kép a hasonlat is, amely abban különbözik a metaforától, hogy a fogalmi és a képi sík között nem azonosítás, hanem egy kevésbé szoros kapcsolat, a hasonlitás ismerhetô fel - nyelvi 
szempontból is: „Szeretlek, mint anyját a gyermek...”. A továbbiakban ennek moduláló szerepe lehet.

\section{A metafora mint kutatási módszer}

A világ megismerésében a metaforának kiemelt szerepe van. Bencze Lóránt azt a felfogást képviseli, miszerint a szóképek nem tekinthetôk valamiféle „szemantikai balesetnek”, hanem a gondolkodás és a kommunikáció nélkülözhetetlen eszközei: a nyelv ,szükségképpen metaforikus, nemcsak a költészetben, hanem a köznyelvben, sôt a tudományos nyelvben is" (Bencze, 1996, 284. o.). A metafora meggyőződése szerint ,az emberi gondolkodás szükségszerú velejárója” (Bencze, 1996, 271.o.).

A fentiekben láttuk, hogy a metafora olyan nyelvi eszköz, melynek segítségével képesek vagyunk absztrakt tartalmak konkrét módon való kifejezésére. Érthetô tehát, hogy a metafora-vizsgálat a 80-as évektől kezdve egyre gyakoribb a tudományos kutatásokban, amikor olyan jelenségekről van szó, amelyek másként nem vagy nehezen értelmezhetôk, hiszen lehetôvé teszik a nehezen verbalizálható és tudatosítható tartalmak előhívását, feltárását is (Vámos, 2003).

Az utóbbi években egyre több kutató ismerte fel, hogy a kognitív metaforaelmélet teoretikus felvetései helytállóak, s módszertana multidiszciplináris keretet nyújt bonyolult érzelmi és kognitív elemeket is tartalmazó struktúrák vizsgálatához, változásuk követéséhez (Baranyainé Kóczy, 2017, Falus, 2006).

Mindezt alátámasztandó utalunk a Magyarországon is látványosan terjedő coaching módszerre. A business coaching vezetőknek, menedzsereknek, de egész csapatoknak is segít projektek hatékony kivitelezésében, konfliktusok kezelésében. A kreatív coaching-módszerek között említik meg (Werhle, 2019) a metafora technikát:

- akcióorientált coaching technika

- intervenciós, konfrontatív módszer

- átkeretezés

- metafora

- imagináció, stb.
A hétköznapi, párkapcsolati coachingban két fogalomtartomány között keresnek megfeleléseket. Egy konkrét példával élve az Utazás és a Szerelem fogalmi tartomány egymással való azonosítása révén a fogalmi metafora (A szerelem utazás), a leképezéssel alkotott szókapcsolatok, metaforikus nyelvi kifejezések (hosszú utat tettünk meg) révén történik meg az élmény, a kapcsolati nehézségek megértése, feldolgozása (Kövecses, 2005):

$\begin{array}{ll}\text { Forrás: UTAZÁS } & \text { Cél: SZERELEM } \\ \text { Az utasok } & \text { A szerelmesek } \\ \text { A jármű } & \text { A szerelmi kapcsolat } \\ \text { Az utazás } & \text { A kapcsolatot alkotó események } \\ \text { A megtett távolság } & \text { A kapcsolatban elért haladás } \\ \text { Az úton lévő akadályok } & \text { A kapcsolat nehézségei } \\ \text { Válaszutak } & \text { A kapcsolat célja }\end{array}$

A pedagógusképzésben kulcskérdés, hogy a pedagógiai, pszichológiai fogalmakat a hallgatók hogyan értelmezik. Értik-e egyáltalán? Mekkora nehézséget jelent számukra, hogy a fogalmak természetüknél fogva mindig ugyanarra vonatkoznak, miközben a róluk alkotott elképzelések az elméletek sajátosságainak megfelelően különbözhetnek (Csapó, 1998, Vámos, 2001)?

Különböző kutatások igazolják, hogy a pedagógiai, pszichológiai fogalmaink megértéséhez, a fogalmak mögötti jelentés vizsgálatához a metafora mint kutatási módszer tökéletesen használható.

A pedagógusi tevékenységhez kapcsolódó metaforák gyűjtésére többféle eljárás áll rendelkezésre (Vámos, 2003), melyek közül néhányat bemutatunk.

A Hasonlat esetében az alábbi nyelvtani formulák, gyakorlatilag kötőszók alkalmazását várjuk a vizsgálati személyektől egy meghatározott célfogalom értelmezésére:

Mint

Mintegy

Mintha

Miként

Akár

Gyanánt

Valamiként

Olybá, stb. 
Ennek egy változatával találkozunk Fenyő Imre (2006) a Debreceni Egyetem Bölcsészettudományi Karának Neveléstudományi Tanszékén végzett OTKA kutatásában, melyet középiskolások körében végzett $A z$ iskola olyan, mint... mondat befejezése az alábbi forrásfogalomköröket rajzolta elő:

- börtön (példák: laktanya, zárka, rabszolgatartó ültetvény, zárda, elmegyógyintézet, koncentrációs tábor)

- (együtt)múködés (példák: méhkaptár, hangyaboly, gépezet, kinyíló virág, zakatoló vonat)

- univerzum (példák: város, világ, ország, tenger, paletta, piac),

- adatbázis (példák: világháló, könyvtár, múzeum, tudáshalmaz),

- környezet (példák: rom, palota, csatatér),

- eszköz (példák: lépcsőfok, mankó, lehetőség, segítség, gyógyszer, reménysugár).

A válaszok arra utalnak, hogy az iskola mint célfogalom különböző, gyakran szélsőséges érzelmeket is hordozó jelentéshorizonttal rendelkezik.

Metafora-provokáció egy körülhatárolt fogalomkörből várja a vizsgálati személyek választását adott fogalom, jelenség értelmezéséhez. Például „A szülők (tanulók) sokféleképpen gondolkodnak a tanárokról. Az alábbi listáról válassza ki azt a hatot, amelyek Ön szerint leginkább illenek a tanárra!" felszólításra érkezett válaszok (Szivák, 2002):

$\begin{array}{ll}\text { Állatidomár } & \text { Őrmester } \\ \text { Bíró } & \text { Pilóta } \\ \text { Edző } & \text { Rabszolga } \\ \text { Eladó } & \text { Rendezó } \\ \text { Gazdasszony } & \text { Színész } \\ \text { Idegenvezető } & \text { Szobrász } \\ \text { Karmester } & \text { Szolga } \\ \text { Kereskedő } & \text { Szülő } \\ \text { Kertész } & \text { Vendéglátó } \\ \text { Múvész } & \end{array}$

Szivák Judit eredményei a tanár célfogalom tipikus képei vonatkozásában nagymértékben egybecsengenek Ben-Peretz és tsai (1996, id. Szivák, 2002) tapasztalataival:

$\begin{array}{ll}\text { Állatidomár } & \text { Állatorvos } \\ \text { Kereskedő } & \text { Karmester } \\ \text { Bábművész } & \text { Showman }\end{array}$

Bíró

Az. RWCT-program (Reading and Writing for Critical Thining - Olvasás és írás a kritikai gondolkodásért) is alkalmaz olyan kooperatív technikákat, interaktív és reflektív tanulási módszereket, amelyekkel hatékonyabbá lehet tenni a tanítás-tanulás folyamatát, továbbá közelebb lehet hozni nehezen értelmezhető, megfogalmazható fogalmakat, jelenségköröket (Fábián, 2015).

Kimondottan kedvelt eljárás az Ötsoros, ami egy speciális versformát jelent - a ráhangolódás szakaszában az elôzetes ismeretek felidézését, a reflektálás szakaszában pedig az összegzést szolgálva. Ennek formája:

1. sor: egy szó, maga a téma (1 főnév)

2. sor: két szó, a téma jellemzése ( 2 melléknév)

3. sor: három szó, a témával kapcsolatos cselekvések (3 ige vagy igenév)

4. sor: négy szó, a témával kapcsolódó személyes érzések, gondolatok megfogalmazása (4 szó)

5. sor: egy szó, a téma lényegének újrafogalmazása, összefoglalása, szinonimája (1 szó)

Ennek a módszernek ismertek további módszervariánsai, mint például a négysoros, hatsoros.

Hasonló elven múködik a Gyémánt-technika (lásd: 1. ábra).

1. ábra: A gyémánt (forrás: a Szerzố)

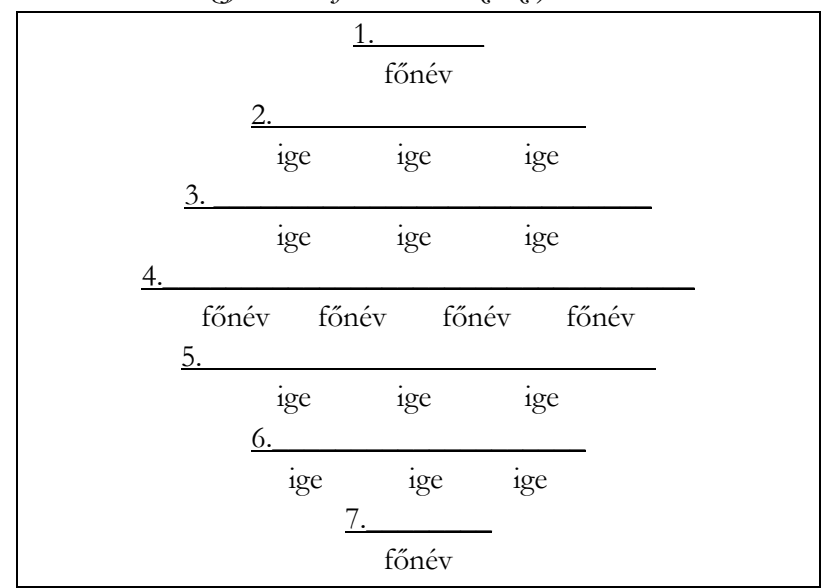


A provokált metaforára emlékeztet a Bárdossy Ildikó és Dudás Margit (2011) által ismertetett eljárás, melyben Szűcs Édua invenciózus képeit használják hívóingerként: Erról a képról az jut eszembe...

A képeket szerzői jogi aggályok miatt nem áll módunkban közölni.
A Metafora-hálót táblázatos analógiával Vámos Ágnes (2001) alkalmazta egyetemisták körében (lásd: 1. táblázat).

Az instrukció:

„Gondolkodjon igy: ha az iskola színház, akkor a tanár..."

1. táblázat: Metafora-báló (forrás: Vámos, 2001)

\begin{tabular}{|l|l|l|l|l|l|}
\hline Iskola & Tanár & Tanuló & Nevelés & Tanulás & Tanítás \\
\hline színház & & & & & \\
\hline & eladó & & & & \\
\hline & & versenyző & & & \\
\hline & & & faragás & & \\
\hline & & & & várépítés & \\
\hline & & & & & \\
\end{tabular}

Látjuk tehát, hogy mindegyik metafora-technikának az a célja, hogy a vizsgált személy a szókép valamelyik formáját használja fel a válaszadáshoz.

\section{Módszer}

A Debreceni Református Hittudományi Egyetem Kölcsey Ferenc Tanítóképzési Intézetében a végzős tanítójelölt hallgatók kéthónapos összefüggő tanítási gyakorlatához pályaszocializációs tréning kapcsolódik. A tréningen alkalmazott gyakorlatok adták az ötletet, hogy egyrészt a szerzett tapasztalataik, benyomásaik feldolgozásához, másrészt az el méleti tanulmányaik gyakorlattal való szembesítése, megerősítése szándékával éljünk a metaforamódszer alkalmazásának lehetőségével.

Azt feltételeztük, hogy a metafora-módszer a pedagógus professzió e sajátos területén, a közoktatási/köznevelési rendszer meghatározott fázisában, az alsó tagozaton dolgozó tanítók, így a tanítójelöltek körében is alkalmazható, képzés- és pályaadekvát felismerésekhez vezető eljárás.

\section{Minta}

A vizsgálati mintába három évfolyam összesen 45 hallgatója tartozott (lásd: 2. táblázat). 
2. táblázat: A vizsgálati minta (forrás: saját szerkesz̨tés)

\begin{tabular}{|c|c|}
\hline Tanév & Hallgatói létszám \\
\hline $2016 / 17$. & 16 fő \\
\hline $2017 / 18$. & 13 fő \\
\hline $2018 / 19$. & 16 fó \\
\hline Összesen: & 45 fó \\
\hline
\end{tabular}

A három évfolyamon mindössze két férfi hallgató volt, így a minta tagolását nem tartottuk indokoltnak.

\section{Eszköz}

A metafora-módszer variánsai közül a mondatbefejezéssel éltünk az alábbiak szerint: „Mondatbefejezés. Kérem, fejezze be az alábbi mondatokat!

A tanító (olyan) ...

A tanuló (olyan) ...

A tanítás (olyan) ...

Az iskola (olyan) ..."

A pályaszocializációs tréningen indoklást is kértünk, amik megbeszélésére kiscsoportban került sor - jelen tanulmányban ennek ismertetésére nem térünk ki.

\section{Eredmények}

Az eredmények feldolgozásához a tartalomelemrés módszerét választottuk: az egyes célfogalmakhoz asszociált metaforákat a forrásfogalmak tartalmi összefüggései szerinti kategóriákba rendeztük - így a kvantitatív és kvalitatív elemzés igénye egyaránt kielégülhet.

A tanitó célfogalom esetében öt forrásfogalmi csoport volt felismerhető. A vizsgálati személyek jelentős köre (37\%-uk) a gyerekek terelését, irányítását emelte ki a

- pásztor (tereló),

- iránytú (iránymutató),

- vezetô fogalmak (sôt volt, aki még a jószándékú jelző alkalmazását is fontos vélte!) használatával.
14 fö (11\%) a gyermekek szükségletének kielégítését tartotta a legfontosabb forrásfogalomnak az alábbi forrásfogalmakat alkalmazva:

- anya,

- tyúkanyó,

- második anya (pótanya).

Hasonló, bár léptéknyi különbség érzékelhető három fó esetében $(6,66 \%)$, akik a gyerek számára mindent előteremtő szerepet hangsúlyozták a

- varázsló,

- Tündérkeresztanya metaforákkal.

Öt hallgató ( $11 \%$ ) a tudásátadást, ismeretközvetítést tartotta fontosnak:

- tudós,

- bagoly

Négyen $(8,88, \%)$ a klasszikus

- színész,

- előadó,

- híresség pozíciót emelték ki.

S volt egy (2,2\%) az eddigi kategóriákba nem sorolható metafora is, a Fônix-madár, ami egyrészt klasszikus debreceni szimbólumnak tekinthető, másrészt az állandó megújulási képességet emeli ki, így feltételezhetôen valamely személyes megtapasztalás áll mögötte.

A tanuló célfogalomhoz négy forrásfogalom társítható a hallgatói metaforáknak köszönhetően. A vizsgálati személyek 37 \%-a (17 fó) az élet, a fejlódés lehetőségét magában hordozó metaforákat fogalmazott meg:

- rügy,

- tojás,

- mag,

- gyökér.

Azt, hogy már egy elért fejlettségi szinten lévő gyerekek lépnek be az alsó tagozatra, s számítanak a tanító segítségére a továbbfejlődésben, hordozza magában az ugyancsak 37 \%-nyi (17 fó)

- növény,

- virág,

- madár,

- sôt az Aladdin metafora is. 
A saját szerep, jelentőség, feladat, a formálás, beavatkozás igénye jelenik meg 22,2 \% esetében (10 fö) a

- faragásra váró faanyag,

- kőtömb,

- agyag,

- anyag formájában.

Egy hallgató $(2,2 \%)$ egy igen furcsa metaforával élt: a kiselefánt, aki tigrisnek képzelni magát metaforát használta. A gyermekek esetlensége, koordinációs problémái, önértékelési zavarai, nevelési problémái állnak magyarázatként rendelkezésre.

A tanitás célfogalom forrásfogalmi kategóriái kiegyenlítettebb képet mutatnak: 13 fó $(28,8 \%)$ a technikai kivitelezés, a módszertani megvalósítás élményszerűségét emeli ki a

- Rubik-kocka,

- kincsesláda,

- búgócsiga,

- játék metaforák révén.

Közel azonos (12 fó, 26,6%) az élet-analógia megjelenése a

- kotlási folyamat,

- kertészkedés (nyírbálás, gyomlálás, ápolás),

- víz (egy-egy csepp víz),

- öntözés metaforákban, illetve

az alkotás, formálás, valamilyen érték létrehozását jelző

- hivatás,

- mûvészet,

- teremtés fogalmak által sugallva.

A nehézségekre, a kiegyenlítetlenségre, kiszámíthatatlanságra utalnak a

- hullámvasút,

- kirándulás,

- utazás,

- izgalmas négyévados sorozat metaforák (8 fö, $17,4 \%)$.

$\mathrm{Az}$ iskola célfogalom forrásfogalmai egyszerre tekinthetôk közhelyszerūnek és meglepőnek. A vizsgálati személyek 42 \%-a (19 fö) az intézmény oltalmat, védelmet nyújtó jellegét hangsúlyozza, amikor az
- otthon,

- második otthon,

- fészek,

- sôt a palota metaforákat használja - ez utóbbiban a hátrányos helyzet is felsejlik.

17 fó $(37 \%)$ az ismeretszerzés fontosságára utalnak a

- lehetőségek tárháza,

- tudás háza,

- múhely metaforák.

A társadalom múködésének modellálása, a szociális tanulás színtere mutatkozik meg a

- mini város (mini falu),

- piramis,

- diktatúra forrásfogalmaknak köszönhetően (8 fö, $17 \%$ ).

El se tudjuk képzelni, milyen személyes tapasztalatokra tettek szert gyakorlatuk során az iskolai osztályok fegyelmezése terén azok a hallgatók, akik:

- a cirkusz,

- a méhkas,

- a tömegkatasztrófa,

- a káosz metaforákat használták (6 fó, 13 \%).

Itt szembetűnő, hogy bár vártuk, két forrásfogalom nem jelent meg az értelmezés során: az előzmények (tanuló, tanítás) ismeretében hiányoljuk az „iskola - kert” fogalom és kép összekapcsolását, valamint a szakirodalmi eredmények (Vámos, 2001) okán értetlenül állunk a klasszikus színház-kép elmaradása előtt.

\section{Megvitatás}

Közel négy évtizedes tréningvezetésben szerzett tapasztalataink alapján meggyőződésünk, hogy a pályaszocializációs tréningek jelentős szerepet töltenek be a tanítóvá válás folyamatában:

- az önreflexió kultúráját erősítik,

- az életstratégia, pályakép ki- és átgondolására nyújtanak lehetőséget és

- segítenek a felmerülő problémák megoldásában, az élmények, tapasztalatok feldolgozásában. 
Végzős, összefüggő gyakorlatukon lévő tanítójelölt hallgatók körében a metafora-módszer alkalmazása során sajátos fogalmi kör, asszociációs háló rajzolódik elénk. Pálya- és élethelyzet-specifikusnak tekinthetô, hogy vizsgálati személyeink a tanító célfogalom kapcsán a gyermeki intellektuális és érzelmi szükségletek kielégitésére fókuszálnak, a tanítványokban az élet, a fejlődés lehetőségét látják elsődlegesen. Ugyanakkor a pályájuk kezdetén szembesülve valós élethelyzetekkel aggályosnak vélik saját módszertani hiányosságaikat és a nevelési helyzetek megoldásának problémás voltát.

A pályaszocializációs tréning formája nemcsak keretet adott, hanem védettséget is nyújtott, s hozzásegített ahhoz, hogy felismerjék hallgatóink, mindezen nehézségekben, nehézségekkel nincsenek egyedül, hasonló problémákkal küzdenek hallgatótársaik is.

Vizsgálatunk alátámasztotta azt a feltételezésünket, hogy az alsó tagozatos gyerekek nevelésére készülő tanítójelöltek körében - akár tréningkeretek között - is eredményesen alkalmazható a metaforamódszer.

\section{Korlátozások}

A fentiekben leírt eredmények a minta alacsony volta miatt természetesen csak a vizsgálatban részt vevő tanítójelöltekre vonatkoztathatóak.

\section{Konklúzió}

A metafora-módszer alkalmazására irányuló vizsgálatunk saját munkásságunkban első próbálkozásnak tekintendő, de hozadéka miatt mindenképpen várható folytatása. A jövőben természetesen igyekszünk kiküszöbölni a minta méretével kapcsolatos problémákat, keressük a megoldást kvantitatív eljárások szélesebb körének bevonására, s mélyreható elemzés alá kívánjuk vetni a metafora-választások indoklását.

Eredményeink egyértelműen igazolják, hogy a metafora-módszer a célfogalom különböző elemeire való utalás révén alkalmas hallgatóink sajátos as- pektusú megismerésére. Látjuk annak a lehetőségét is, hogy összehasonlítsuk a tanító pályára készülés különböző szintjein álló hallgatók, továbbá a pálya eltérő fázisaiban dolgozó tanítók által asszociált metaforákat.

Úgy véljük, a kvantitatív és kvalitatív elemzés lehetőséget nyújt annak megvilágítására is, hogyan értelmezik hallgatóink a pedagógiai, pszichológiai fogalmakat, metaforáik eltérnek-e, $\mathrm{s}$ ha igen, milyen vonatkozásban a pedagógus professzió más szintjein dolgozókétól, jellemző-e rájuk pálya-adekvát fogalomértelmezés.

\section{IRODALOM}

Arisztotelész (1974). Poétika. Magyar Helikon, Budapest.

Baranyiné Kóczy, J. (2017). Mi a kulturális metafora? Magyar Nyelvoór, 140, 404-425.

Bárdossy, I. és Dudás, M. (2011). Pedagógiai nézetete. Tanári mesterképzést bevezetố tanulási/tanitási programoktatók és hallgatók számára. Pécsi Tudományegyetem, Pécs.

Bencze, L. (1996). A szóképek, az alakzatok és a metaforaalkotás. Trópusok és figurák. In: Szathmári, I. (Ed.). Hol tart ma a stilisztika? Stiluselméleti tanulmányok. Nemzeti Tankönyvkiadó, Budapest, pp. 234-309.

Csapó, B. (1998). Az iskolai tudás vizsgálatának elméleti keretei és módszerei. In: Csapó, B. (Ed.). Az iskolai tudás. Osiris Kiadó, Budapest. pp. 11-37.

Fábián, Gy. (2015). Kritikai gondolkodás az osztályteremben. Gondolat Kiadó, Budapest.

Fábián, P., Szathmári, I. és Terestyéni, F. (1958). A magyar stilisztika vázlata. Tankönyvkiadó, Budapest.

Falus, I. (2006). A tanári tevékenység és a pedagógusképzés új útjai. Gondolat Kiadó, Budapest.

Fenyô, I. (2006). Az iskola olyan, mint... Hogyan élik meg a tanulók az iskolát? (Letöltés: 2019. 02. 17.) Web: http://www.osztalyfonok.hu cikk.php? id $=341$ 
Kövecses, Z. (2005). A metafora. Gyakorlati bevezetés a kognitiv metaforaelméletbe. Typotex Kiadó, Budapest.

Szivák, J. (2002). A pedagógusok gondolkodásának kutatási módszerei. Műszaki Könyvkiadó, Budapest.

Vámos, Á. (2003). Metafora a pedagógiában. Gondolat Kiadói Kör, Budapest.
Vámos, Á. (2001). Metafora felhasználása a pedagógiai fogalmak tartalmának vizsgálatában. $M a-$ gyar Pedagógia, 1, 85-108.

Werhle, M. (2019). A 100 legjobb coaching gyakorlat. Coachok gyakorlati kézikönyve. Z-Press Kiadó, Miskolc. 